\title{
Inhalation Toxicity of Bisphenol A and Its Effect on Estrous Cycle, Spatial Learning, and Memory in Rats upon Whole-Body Exposure
}

\author{
Yong Hyun Chung, Jeong Hee Han, Sung-Bae Lee and Yong-Hoon Lee \\ Inhalation Toxicity Research Center, Chemical Research Bureau, Occupational Safety and Health Research Institute, \\ Korea Occupational Safety and Health Agency, Daejeon, Korea
}

(Received January 31, 2017; Revised March 14, 2017; Accepted March 14, 2017)

\begin{abstract}
Bisphenol A (BPA) is a monomer used in a polymerization reaction in the production of polycarbonate plastics. It has been used in many consumer products, including plastics, polyvinyl chloride, food packaging, dental sealants, and thermal receipts. However, there is little information available on the inhalation toxicity of BPA. Therefore, the aim of this study was to determine its inhalation toxicity and effects on the estrous cycle, spatial learning, and memory. Sprague-Dawley rats were exposed to $0,10,30$, and $90 \mathrm{mg} / \mathrm{m}^{3}$ BPA, $6 \mathrm{hr} /$ day, 5 days/week for 8 weeks via whole-body inhalation. Mortality, clinical signs, body weight, hematology, serum chemistry, estrous cycle parameters, performance in the Morris water maze test, and organ weights, as well as gross and histopathological findings, were compared between the control and BPA exposure groups. Statistically significant changes were observed in serum chemistry and organ weights upon exposure to BPA. However, there was no BPA-related toxic effect on the body weight, food consumption, hematology, serum chemistry, organ weights, estrous cycle, performance in the Morris water maze test, or gross or histopathological lesions in any male or female rats in the BPA exposure groups. In conclusion, the results of this study suggested that the no observable adverse effect level (NOAEL) for BPA in rats is above $90 \mathrm{mg} / \mathrm{m}^{3} / 6 \mathrm{hr} /$ day, 5 days/week upon 8-week exposure. Furthermore, BPA did not affect the estrous cycle, spatial learning, or memory in rats.
\end{abstract}

Key words: Bisphenol A, NOAEL, Whole-body inhalation toxicity, Estrous cycle, Morris water maze test, Endocrine disruptor chemicals

\section{INTRODUCTION}

Bisphenol A [BPA; $\left(\mathrm{CH}_{3}\right)_{2} \mathrm{C}\left(\mathrm{C}_{6} \mathrm{H}_{4} \mathrm{OH}\right)_{2}$, CAS No. 80-0507], white to tan flakes or a powder with a mild odor, is a monomer used in a polymerization reaction in the production of polycarbonate plastics (1). BPA is manufactured through the combination and condensation of acetone with phenol under high temperatures and a low $\mathrm{pH}$, followed by the purification of the product (2). BPA is one of the largestvolume chemicals manufactured worldwide; thus, its global production reached 4.6 million tons in 2012 (3). It has been used in many consumer products, including plastics, polyvi-

Correspondence to: Yong-Hoon Lee, Inhalation Toxicity Research Center, Chemical Research Bureau, Occupational Safety and Health Research Institute, Korea Occupational Safety and Health Agency, 339-30 Expo-ro, Yuseong-gu, Daejeon 34122, Korea E-mail: dvmone@kosha.or.kr

This is an Open-Access article distributed under the terms of the Creative Commons Attribution Non-Commercial License (http:// creativecommons.org/licenses/by-nc/3.0) which permits unrestricted non-commercial use, distribution, and reproduction in any medium, provided the original work is properly cited. nyl chloride, food packaging, dental sealants, and thermal receipts, and humans are usually exposed to BPA through inhalation, diet, and dermal contact (4).

BPA is widely known as an endocrine disruptor chemical (EDC), i.e., a chemical that mimics, alters, and blocks the endogenous hormonal activity. Changes in hormone levels, actions, or receptors through exposure to EDCs disrupt not only the structure and function of the brain but also the regulation of hormones by the brain (1). There is much evidence showing that BPA mimics estrogens and is similar to other estrogenic disruptors. It can also bind to the androgenic receptor and disrurpt the action of androgens $(5,6)$.

Numerous studies have reported changes in reproductive hormones caused by the exposure to BPA in experiments (7-9). Effects of BPA exposure on the oocyte, developing reproductive tract, and sexual maturation have been observed in female rats and mice during the perinatal period (10-12). In human studies, BPA exposure has been related to hormone-dependent tumors such as breast and prostate cancer, endocrine disorders such as precocious puberty, and metabolic disorders such as obesity and polycystic ovary syndrome (13). In addition, many studies have reported that 
BPA exposure affected the brain development and behaviors during the gestational period. Perinatal or neonatal BPA exposure was shown to influence the brain sexual differentiation $(14,15)$ and neuronal behavior, leading to cognitive deficits as well as learning and memory impairment (16$20)$. Furthermore, BPA could affect the juvenile social behaviors in mice $(21,22)$.

Although there have been many studies characterizing the BPA effects on estrogenic activity and the brain, its effects have been rarely studied in laboratory animals by using the inhalation route. Therefore, this study was conducted to characterize the potential inhalation toxicity of BPA upon the whole-body exposure of Sprague-Dawley (SD) rats and its effects on the estrous cycle, spatial learning, and memory.

\section{MATERIALS AND METHODS}

Animal maintenance. Seven-week-old, specific-pathogen-free SD rats of both sexes were purchased from Bio Genomics Inc. (Gapyeong, Korea) and acclimated for 1 week. The room was maintained at a temperature of $22 \pm$ $3^{\circ} \mathrm{C}$, relative humidity of $50 \pm 20 \%, 12: 12$-hr light : dark cycle, and fresh air ventilation $(10 \sim 15$ changes per hr). The rats were housed singly in stainless steel wire mesh cages (width $750 \mathrm{~mm} \times$ length $220 \mathrm{~mm} \times$ height $180 \mathrm{~mm}$ ) and had free access to a commercial rodent diet (PMI Nutrition International, Inc., St. Louis, MO, USA) and filtered tap water. The study was conducted at the Occupational Safety and Health Research Institute, and was approved by the Institutional Animal Care and Use Committee (IACUC0101).

Test chemical and exposure system. BPA (lot no. 033107) was obtained from Samchun Chemical (Pyeongtaek, Korea). A whole body stainless steel exposure chamber (SIS-20RG, Shibata, Niigata, Japan), including a dust generator (DM-800 and DF-3, Shibata), was used to expose rats to BPA at a concentration of $0,10,30$, or $90 \mathrm{mg} / \mathrm{m}^{3}$ for $6 \mathrm{hr} /$ day, 5 days/week for 8 weeks. Inhalation exposure procedures were conducted from 10:00 to 16:00. The experimental design was based on the routine working schedule of employees and the major exposure route for the test substance.

Conditions in inhalation chambers. The temperature, relative humidity, pressure, and air ventilation in the chambers were recorded using an environmental controller (ICS20RG, Shibata). A personal sampler (Sensidyne, St. Petersburg, FL, USA) was used for sampling BPA at a flow rate of $2 \mathrm{~L} / \mathrm{min}$ through the exposure chamber. The particles were collected from the center of the chamber and captured on mixed cellulose ester membrane filters (pore size: 4.5 $\mu \mathrm{m}$, diameter: $37 \mathrm{~mm}$; Millipore, Billerica, MA, USA). The distribution of particle sizes was determined using an
Anderson sampler (AN-200, Sibata, Tokyo, Japan) at a flow rate of $28.3 \mathrm{~L} / \mathrm{min}$ for $20 \mathrm{~min}$.

Experimental groups. A total of 80 rats (40 males and 40 females) were randomly assigned to the following four groups (10 animals per sex per group): control $\left(0 \mathrm{mg} / \mathrm{m}^{3}\right)$, low dose $\left(10 \mathrm{mg} / \mathrm{m}^{3}\right)$, middle dose $\left(30 \mathrm{mg} / \mathrm{m}^{3}\right)$, and high dose $\left(90 \mathrm{mg} / \mathrm{m}^{3}\right)$. All rats were euthanized after 8 weeks of exposure. The BPA concentrations were selected using a scaling factor of 3 because a previous study has reported decreased that a decreased body weight or decreased liver and kidney organ weights were observed at BPA concentrations between 50 and $150 \mathrm{mg} / \mathrm{m}^{3}$ (23).

Clinical signs and body weight. All animals were examined once daily for mortality and clinical signs, and weighed individually immediately before the inhalation exposure on day 1 and once per week thereafter.

Hematology. Five male and five female rats in each group were fasted overnight before the necropsy and blood collection. Blood samples were taken from the abdominal aorta using a syringe with a 21-gauge needle under isoflurane anesthesia (Ilsung Pharm, Seoul, Korea) and collected into vacutainers containing EDTA-3K (Becton Dickinson, Franklin Lakes, NJ, USA). The samples were analyzed within 20 min of collection using an automated hematology analyzer (F-820, Sysmex, Kobe, Japan) The following parameters were determined in this study: total erythrocyte counts, hemoglobin concentration, hematocrit, mean cell volume, mean cell hemoglobin, mean cell hemoglobin concentration, platelet count, and whole leukocyte counts.

Serum biochemistry. Blood samples were centrifuged at 3,000 rpm for $10 \mathrm{~min}$ within $1 \mathrm{hr}$ after the collection. The sera were stored at $-80^{\circ} \mathrm{C}$ until analysis. The following serum chemistry parameters were evaluated using an automated analyzer (TBA-20FR, Toshiba Medical Systems, Tochigi, Japan): total protein, albumin, blood urea nitrogen, creatinine, total bilirubin, alanine aminotransferase, aspartate aminotransferase, alkaline phosphatase, glucose, and total cholesterol.

Necropsy, organ weight, and histopathological evaluations. Gross examinations of the organs in the cranial, thoracic, and abdominal cavities of the rats were conducted. The absolute and relative (organ to body) weights of the brain, thymus, lung, heart, liver, spleen, kidneys, adrenal glands, testes, and ovaries were measured. The following tissues were removed from each animal at necropsy: the liver, kidney, adrenal glands, heart, lungs, cerebrum, cerebellum, pituitary gland, spleen, seminal vesicles, prostate, testes, epididymides, ovaries, uterus, vagina, tongue, trachea, esophagus, thymus, thyroid gland, stomach, urinary bladder, small/large intestine, eyes/harderian glands, skeletal muscles, sciatic 
nerve, pancreas, aorta, mesenteric lymph node, femur, larynx, and nasal cavity. The nasal cavity was sectioned at three levels: posterior to the upper incisors; incisive papilla; and first molar teeth. The eyes were fixed in Davidson's solution, and the testes in Bouin's solution. Other organs were preserved in $10 \%$ neutral buffered formalin. All organs were embedded in paraffin, sectioned at $3 \sim 4 \mu \mathrm{m}$, stained with hematoxylin and eosin, and examined microscopically under low - and high - power fields.

Vaginal cytology. Five female rats in each group were evaluated for changes in their estrus cycles for 9 days as previously described (24). Vaginal smears were collected every afternoon, stained with a Giemsa solution, and observed microscopically. The estrous cycle, reflected by the vaginal smear, was characterized as proestrus, estrus, metestrus, or diestrus according to the features of each cell type.

Morris water maze test. Five male and five female rats from the control and $90 \mathrm{mg} / \mathrm{m}^{3}$ groups were evaluated for their spatial learning ability and memory for 3 days as previously described (25). A circular swimming pool $(150 \mathrm{~cm}$ in diameter and $50 \mathrm{~cm}$ in height) was filled to a depth of $30 \mathrm{~cm}$ with water that was maintained at $25 \pm 2^{\circ} \mathrm{C}$ and dyed with a white colored dye (Tempera; Fine Art Supplies, Auckland, New Zealand). Four equally spaced points were designated as the east, south, west, and north around the edge of the pool. An escape platform was set $1 \mathrm{~cm}$ below the water surface. The paths of the mice were recorded using an HVS image-tracking system (HVS Image, Hampton, UK). Each subject performed the task three times daily at intervals of $1 \mathrm{~min}$, and the trials started by placing a rat in the water so that the animal faced the wall surrounding the pool. The rats were allowed to swim to the platform, and the escape latency was recorded.

Statistical analyses. Differences among the groups in various parameters were determined using the SPSS (version 19.0, IBM, Chicago, IL, USA) or SigmaPlot (version 13.0, SYSTAT, San Jose, CA, USA) software. The homogeneity of variance was analyzed by the Levene's test, followed by either one-way analysis of variance for samples with homogenous variance or the Kruskal-Wallis test for samples with heterogeneous variance. Duncan's or Dunnett's multiple test was used to compare the result of each experimental group with that for the control group if the first result was statistically significant.

\section{RESULTS}

Characterization of BPA particles in aerosols and particle size. The average concentrations of BPA during the study were $10.51 \pm 1.59 \mathrm{mg} / \mathrm{m}^{3}, 30.52 \pm 4.28 \mathrm{mg} / \mathrm{m}^{3}$, and $88.3 \pm 8.64 \mathrm{mg} / \mathrm{m}^{3}$ for the low, medium, and high concen-
Table 1. Concentrations of the bisphenol A in exposed groups

\begin{tabular}{lcccc}
\hline \hline \multirow{2}{*}{$\begin{array}{c}\text { Groups } \\
\left(\mathrm{mg} / \mathrm{m}^{3}\right)\end{array}$} & \multicolumn{4}{c}{ Concentration $\left(\mathrm{mg} / \mathrm{m}^{3}\right)$} \\
\cline { 2 - 5 } & Establishment & Upper & Lower & Mean $\pm \mathrm{SD}$ \\
\hline G1 (0) & 0.0 & 0.0 & 0.0 & $0.0 \pm 0.0$ \\
G2 (10) & 10.0 & 13.3 & 7.3 & $10.5 \pm 1.59$ \\
G3 (30) & 30.0 & 39.9 & 20.0 & $30.52 \pm 4.28$ \\
G4 (90) & 90.0 & 111.84 & 73.75 & $88.3 \pm 8.64$ \\
\hline
\end{tabular}

SD, standard deviation.

Table 2. Particle size distribution analysis of bisphenol $\mathrm{A}$

\begin{tabular}{|c|c|c|c|}
\hline Size $(\mu \mathrm{m})$ & Particulate mean (mg) & Ratio (\%) & Total (\%) \\
\hline $0(\geq 11.0)$ & 0.56 & 12.58 & 100.00 \\
\hline $1(7.00 \sim 11.0)$ & 0.28 & 6.29 & 87.41 \\
\hline $2(4.70 \sim 7.00)$ & 1.01 & 22.70 & 81.12 \\
\hline $3(3.30 \sim 4.70)$ & 1.53 & 34.38 & 58.42 \\
\hline $4(2.10 \sim 3.30)$ & 0.80 & 17.98 & 24.04 \\
\hline $5(1.10 \sim 2.10)$ & 0.20 & 4.49 & 6.06 \\
\hline $6(0.65 \sim 1.10)$ & 0.06 & 1.35 & 1.57 \\
\hline $7(0.43 \sim 0.65)$ & 0.00 & 0.00 & 0.22 \\
\hline $\mathrm{BUF}(\leq 0.43)$ & 0.01 & 0.22 & 0.22 \\
\hline
\end{tabular}

BUF, backup filter.

Sampling flow rate: $28.3 \mathrm{~L} / \mathrm{min}$.

Sampling time: $20 \mathrm{~min}$.

tration groups, respectively (Table 1). The sizes of BPA particles mostly ranged from 2.10 to $7.0 \mu \mathrm{m}$, which accounted for $75.06 \%$ of the total distribution (Table 2).

Clinical signs and body weight. No deaths or adverse clinical signs were observed in any rats exposed to any concentration of BPA. The body weights did not significantly change in any male or female rat exposed to any concentration of BPA compared with the control group (data not shown).

Hematology. No statistically significant hematological changes was observed in any of the BPA-exposed groups compared with the control group (data not shown).

Serum biochemistry. Total cholesterol significantly increased $(P<0.05)$ in female rats exposed to 10 and $90 \mathrm{mg} /$ $\mathrm{m}^{3}$ BPA compared to those in the control group (Table 3, 4). There were no changes in the other serum biochemical parameters.

Organ weight. The relative organ weight of the adrenal gland significantly increased $(P<0.05)$ in the male rat exposed to $90 \mathrm{mg} / \mathrm{m}^{3}$ BPA compared to those in the control group (Table 5,6). There was no change in the weight of the other organs.

Gross and histopathological evaluations. No gross lesion was observed in any BPA group. No test substance- 
Table 3. Serum biochemical values in male rats exposed to bisphenol A for 8 weeks

\begin{tabular}{|c|c|c|c|c|c|}
\hline \multirow{2}{*}{ Tests } & \multirow{2}{*}{ Units } & \multicolumn{4}{|c|}{ Groups $\left(\mathrm{mg} / \mathrm{m}^{3}\right)$} \\
\hline & & G1 (0) & G2 (10) & G3 (30) & G4 (90) \\
\hline TP & $\mathrm{mg} / \mathrm{dL}$ & $6.7 \pm 0.3$ & $6.7 \pm 0.2$ & $6.7 \pm 0.2$ & $7.1 \pm 0.5$ \\
\hline BUN & $\mathrm{mg} / \mathrm{dL}$ & $16.5 \pm 0.9$ & $15.8 \pm 2.0$ & $16.9 \pm 2.3$ & $16.8 \pm 2.9$ \\
\hline CR & $\mathrm{mg} / \mathrm{dL}$ & $0.8 \pm 0.04$ & $0.8 \pm 0.04$ & $0.8 \pm 0.07$ & $0.8 \pm 0.04$ \\
\hline TBIL & $\mathrm{mg} / \mathrm{dL}$ & $0.3 \pm 0.15$ & $0.3 \pm 0.05$ & $0.3 \pm 0.07$ & $0.3 \pm 0.04$ \\
\hline ALT & IU/L & $55.2 \pm 7.5$ & $49.6 \pm 6.2$ & $48.8 \pm 4.9$ & $50.6 \pm 5.9$ \\
\hline AST & IU/L & $121.4 \pm 20.4$ & $128.0 \pm 16.5$ & $138.2 \pm 10.9$ & $124.8 \pm 23.7$ \\
\hline ALP & IU/L & $251 \pm 20$ & $306 \pm 67$ & $287 \pm 40$ & $292 \pm 96$ \\
\hline GLU & $\mathrm{mg} / \mathrm{dL}$ & $146.4 \pm 10.8$ & $131.2 \pm 20.6$ & $133.2 \pm 8.5$ & $124.8 \pm 23.7$ \\
\hline $\mathrm{TC}$ & $\mathrm{mg} / \mathrm{dL}$ & $73.8 \pm 6.1$ & $69.0 \pm 15.4$ & $72.0 \pm 8.2$ & $81.6 \pm 7.9$ \\
\hline
\end{tabular}

ALB, albumin; ALP, alkaline phosphatase; ALT, alanine aminotransferase; AST, aspartate aminotransferase; BUN, blood urea nitrogen; CR, creatinine; GLU, glucose; TBIL, total bilirubin; TC, total cholesterol; TP, total protein.

All values are expressed as the mean \pm standard deviation.

Table 4. Serum biochemical values in female rats exposed to bisphenol A for 8 weeks

\begin{tabular}{|c|c|c|c|c|c|}
\hline \multirow{2}{*}{ Tests } & \multirow{2}{*}{ Units } & \multicolumn{4}{|c|}{ "Groups $\left(\mathrm{mg} / \mathrm{m}^{3}\right)$} \\
\hline & & G1 (0) & G2 (10) & G3 (30) & G4 (90) \\
\hline TP & $\mathrm{mg} / \mathrm{dL}$ & $7.5 \pm 0.3$ & $7.4 \pm 0.5$ & $7.6 \pm 0.1$ & $7.8 \pm 0.3$ \\
\hline BUN & $\mathrm{mg} / \mathrm{dL}$ & $18.5 \pm 2.9$ & $16.1 \pm 0.8$ & $20.9 \pm 4.9$ & $18.8 \pm 3.7$ \\
\hline $\mathrm{CR}$ & $\mathrm{mg} / \mathrm{dL}$ & $0.8 \pm 0.04$ & $0.8 \pm 0.05$ & $0.8 \pm 0.04$ & $0.7 \pm 0.05$ \\
\hline TBIL & $\mathrm{mg} / \mathrm{dL}$ & $0.4 \pm 0.05$ & $0.4 \pm 0.09$ & $0.4 \pm 0.08$ & $0.4 \pm 0.07$ \\
\hline ALT & IU/L & $36.2 \pm 2.9$ & $39.2 \pm 4.4$ & $36.2 \pm 7.4$ & $40.6 \pm 8.9$ \\
\hline AST & IU/L & $124.0 \pm 17.0$ & $113.6 \pm 12.5$ & $112.6 \pm 8.0$ & $124.8 \pm 23.7$ \\
\hline ALP & IU/L & $149 \pm 49$ & $145 \pm 38$ & $156 \pm 45$ & $184 \pm 39$ \\
\hline GLU & $\mathrm{mg} / \mathrm{dL}$ & $104.2 \pm 9.1$ & $104.2 \pm 25.3$ & $89.4 \pm 27.8$ & $101.6 \pm 16.1$ \\
\hline $\mathrm{TC}$ & $\mathrm{mg} / \mathrm{dL}$ & $2274 \pm 570$ & $1797 \pm 704^{*}$ & $1548 \pm 422$ & $2062 \pm 596^{*}$ \\
\hline
\end{tabular}

ALB, albumin; ALP, alkaline phosphatase; ALT, alanine aminotransferase; AST, aspartate aminotransferase; BUN, blood urea nitrogen; CR, creatinine; GLU, glucose; TBIL, total bilirubin; TC, total cholesterol; TP, total protein.

All values are expressed as the mean \pm standard deviation.

Significant differences versus the control group: ${ }^{*} P<0.05$.

Table 5. Relative organ weights of male rats exposed to bisphenol A for 8 weeks

\begin{tabular}{lcccc}
\hline \hline \multirow{2}{*}{ Organ weights (\%) } & \multicolumn{4}{c}{ Groups $\left(\mathrm{mg} / \mathrm{m}^{3}\right)$} \\
\cline { 2 - 4 } & $\mathrm{G} 1(0)$ & $\mathrm{G} 2(10)$ & $\mathrm{G} 3(30)$ & $\mathrm{G} 4(90)$ \\
\hline Body weight (g) & $437.7 \pm 25.3$ & $414.4 \pm 20.4$ & $428.6 \pm 30.1$ & $416.0 \pm 26.1$ \\
Adrenal glands & $0.007 \pm 0.002$ & $0.008 \pm 0.001$ & $0.008 \pm 0.003$ & $0.009 \pm 0.002^{*}$ \\
Brain & $0.46 \pm 0.02$ & $0.49 \pm 0.02$ & $0.48 \pm 0.05$ & $0.50 \pm 0.03$ \\
Heart & $0.31 \pm 0.04$ & $0.30 \pm 0.03$ & $0.30 \pm 0.02$ & $0.30 \pm 0.03$ \\
Kidneys & $0.26 \pm 0.04$ & $0.28 \pm 0.02$ & $0.26 \pm 0.03$ & $0.27 \pm 0.02$ \\
Liver & $2.51 \pm 0.14$ & $2.54 \pm 0.07$ & $2.61 \pm 0.37$ & $2.38 \pm 0.28$ \\
Spleen & $0.17 \pm 0.04$ & $0.16 \pm 0.02$ & $0.18 \pm 0.03$ & $0.14 \pm 0.02$ \\
Lung & $0.14 \pm 0.05$ & $0.15 \pm 0.05$ & $0.13 \pm 0.05$ & $0.14 \pm 0.06$ \\
Testes & $0.32 \pm 0.03$ & $0.33 \pm 0.04$ & $0.31 \pm 0.03$ & $0.33 \pm 0.02$ \\
Thymus & $0.11 \pm 0.02$ & $0.16 \pm 0.07$ & $0.12 \pm 0.02$ & $0.13 \pm 0.04$ \\
\hline
\end{tabular}

All values are expressed as the mean \pm standard deviation.

Significant differences versus the control group: ${ }^{*} P<0.01$.

related histopathological change was observed in any organs of the BPA exposed group. All the other lesions were determined to be spontaneous changes that were similar in the control and exposed animals, and were accidental changes not accompanied by any dose-response relationship.

Vaginal cytology. No significant change was observed in any of the BPA groups compared to the control group 
Table 6. Relative organ weights of female rats exposed to bisphenol A for 8 weeks

\begin{tabular}{|c|c|c|c|c|}
\hline \multirow{2}{*}{ Organ weights (\%) } & \multicolumn{4}{|c|}{ Groups $\left(\mathrm{mg} / \mathrm{m}^{3}\right)$} \\
\hline & G1 (0) & G2 (10) & G3 (30) & G4 (90) \\
\hline Body weight (g) & $273.7 \pm 10.4$ & $272.4 \pm 9.6$ & $261.6 \pm 11.9$ & $253.5 \pm 11.4$ \\
\hline Adrenal glands & $0.013 \pm 0.003$ & $0.012 \pm 0.002$ & $0.011 \pm 0.002$ & $0.014 \pm 0.003$ \\
\hline Brain & $0.69 \pm 0.03$ & $0.71 \pm 0.05$ & $0.73 \pm 0.04$ & $0.73 \pm 0.06$ \\
\hline Heart & $0.33 \pm 0.02$ & $0.31 \pm 0.04$ & $0.33 \pm 0.05$ & $0.35 \pm 0.03$ \\
\hline Kidneys & $0.27 \pm 0.04$ & $0.28 \pm 0.03$ & $0.28 \pm 0.02$ & $0.28 \pm 0.04$ \\
\hline Liver & $2.22 \pm 0.24$ & $2.37 \pm 0.31$ & $2.53 \pm 0.30$ & $2.62 \pm 0.35$ \\
\hline Spleen & $0.18 \pm 0.02$ & $0.17 \pm 0.02$ & $0.19 \pm 0.02$ & $0.18 \pm 0.03$ \\
\hline Lung & $0.17 \pm 0.06$ & $0.18 \pm 0.06$ & $0.18 \pm 0.06$ & $0.17 \pm 0.06$ \\
\hline Ovaries & $0.020 \pm 0.004$ & $0.020 \pm 0.004$ & $0.021 \pm 0.007$ & $0.020 \pm 0.006$ \\
\hline Thymus & $0.19 \pm 0.03$ & $0.16 \pm 0.05$ & $0.19 \pm 0.03$ & $0.18 \pm 0.03$ \\
\hline
\end{tabular}

All values are expressed as the mean \pm standard deviation.

(data not shown).

Morris water maze test. No significant change was observed in the $90 \mathrm{mg} / \mathrm{m}^{3}$ BPA group compared to the control group (data not shown).

\section{DISCUSSION}

This study was conducted to evaluate the potential inhalation toxicity of BPA and its effect on the estrogen activity, spatial learning, and memory by repeatedly exposing SD rats for 8 weeks to BPA at concentrations of $0,10,30$, or $90 \mathrm{mg} / \mathrm{m}^{3}$ in the air. Although we found some statistically significant differences in the serum chemistry and organ weights between animals exposed to BPA and those from the control group, no pathological or physiological adverse effect was observed in any test.

No clinically relevant sign was observed in any of the rats exposed to any concentration of BPA. Previous reports have indicated that perinatal or neonatal BPA exposure caused a reduction of the birth weight, slowed the growth, decreased the survival rate, delayed the puberty in the offspring (2629 ), caused gestational diabetes-like symptoms in pregnant animals (30), affected the neurological behavior, and caused the development of prostate and breast cancer in adult animals (31-33). The timing of exposure to BPA during the life cycle may have contributed to the differences between the previous results and our findings.

An increase of total cholesterol was observed in the female rats exposed to 10 and $90 \mathrm{mg} / \mathrm{m}^{3}$ BPA compared to that in the control group. This change was not considered an adverse effect because it was not observed in the males and was not associated with morphological alterations in the liver or thyroid gland (34).

There were statistically significant increases in the relative organ weight of the adrenal glands in the males from the $90 \mathrm{mg} / \mathrm{m}^{3}$ BPA group compared to those from the control group. However, these changes were not regarded as adverse effects because they were not accompanied by an increase in the absolute organ weight of the adrenal glands and the absolute and relative organ weight of the adrenal glands in the females from the $90 \mathrm{mg} / \mathrm{m}^{3}$ BPA group, nor were they associated with histopathological alterations in the adrenal glands (34). Meanwhile, a decrease in the liver and kidney weight, accompanied by a dose-dependent decrease of the body weight, was observed in rats and mice that were exposed to $150 \mathrm{mg} / \mathrm{m}^{3}$ BPA for 13 weeks; however, no histopathological alterations were revealed (23). The higher concentration or longer exposure period may have contributed to the differences between the previous results and our findings.

No significant change was observed in the estrous cycle in any of the BPA groups compared to the control group. Meanwhile, early prepubertal subcutaneous injection of BPA to females on postnatal day 8 accelerated the onset of puberty, resulting in an early opening of the vagina in BPA treatment groups and decreased reproductive parameters, including the estrous cycle and ovary weights (35). It is thought that BPA has stronger effects on reproductive organs of infants than on those of adults because the development of reproductive organs is more susceptible to estrogenic compounds during the period of sexual differentiation of the brain at the infant age (36).

In the Morris water maze test, no significant change was observed in the $90 \mathrm{mg} / \mathrm{m}^{3}$ BPA group compared to the control group. However, in another study, the average escape pathlength was extended in the ICR male mice orally exposed to BPA ( $40 \mu \mathrm{g} / \mathrm{kg} /$ day) for 8 weeks, while no significant effect was observed in the females (37). Differences in species or exposure routes may explain the difference between these results and those obtained in our study. On the other hand, perinatal BPA exposure resulted in sex differences in learning and memory because BPA acts as an antagonist for the androgen receptor in the prefrontal cortex during the perinatal period, inhibiting cognitive ability (38-43).

In conclusion, an 8-week repeated whole-body inhalation 
exposure of rats to three concentrations of BPA did not result in any toxic effects in any test. Thus, the no observable adverse effect level (NOAEL) of BPA for rats was considered to be above $90 \mathrm{mg} / \mathrm{m}^{3}, 5$ days/week for 8 weeks. Moreover, BPA did not affect the estrous cycle or spatial learning and memory in rats. The present study provides useful information regarding the lack of toxicity of inhaled BPA.

\section{ACKNOWLEDGMENTS}

This work was supported by the Korea Occupational Safety and Health Agency, Ministry of Labor, Republic of Korea, and a Grant-in-Aids for chemical hazard assessment.

\section{REFERENCES}

1. Preethi, S., Sandhya, K., Esther Lebonah, D., Venkata Prasad, C., Sreedevi, B. and Pramoda Kumari, J. (2014) Toxicity of bisphenol a on humans: a review. Int. Lett. Nat. Sci., 27, 3246.

2. Staples, C.A., Dorn, P.B., Klecka, G.M., O'Block, S.T. and Harris, L.R. (1998) A review of the environmental fate, effects, and exposures of bisphenol A. Chemosphere, 36, 2149-2173.

3. World BPA production grew by over 372,000 tonnes in 2012 . Available from: https://mcgroup.co.uk/news/20131108/bpaproduction-grew-372000-tonnes.html/.

4. Rochester, J.R. (2013) Bisphenol A and human health: a review of the literature. Reprod. Toxicol., 42, 132-155.

5. Welshons, W.V., Nagel, S.C. and vom Saal, F.S. (2006) Large effects from small exposures. III. Endocrine mechanisms mediating effects of bisphenol A at levels of human exposure. Endocrinology, 147, S56-S69.

6. Lee, H.J., Chattopadhyay, S., Gong, E.Y., Ahn, R.S. and Lee, K. (2003) Antiandrogenic effects of bisphenol A andnonylphenol on the function of androgen receptor. Toxicol. Sci., 75, 40-46.

7. Wetherill, Y.B., Akingbemi, B.T., Kanno, J., McLachlan, J.A., Nadal, A., Sonnenschein, C., Watson, C.S., Zoeller, R.T. and Belcher, S.M. (2007) In vitro molecular mechanisms of bisphenol A action. Reprod. Toxicol., 24, 178-198.

8. Khurana, S., Ranmal, S. and Ben-Jonathan, N. (2000) Exposure of newborn male and female rats to environmental estrogens: delayed and sustained hyperprolactinemia and alterations in estrogen receptor expression. Endocrinology, 141, 45124517.

9. Kawato, S. (2004) Endocrine disrupters as disrupters of brain function: A neurosteroid viewpoint. Environ. Sci., 11, 1-14.

10. Steinmetz, R., Mitchner, N.A., Grant, A., Allen, D.L., Bigsby, R.M. and Ben-Jonathan, N. (1998) The xenoestrogen bisphenol A induces growth, differentiation, and c-fos gene expression in the female reproductive tract. Endocrinology, 139, 2741-2747.

11. Colerangle, J.B. and Roy, D. (1997) Profound effects of the weak environmental estrogen-like chemicalbisphenol A on the growth of the mammary gland of noble rats. J. Steroid Biochem. Mol. Biol., 60, 153-160.
12. Richter, C.A., Birnbaum, L.S., Farabollini, F., Newbold, R.R., Rubin, B.S., Talsness, C.E., Vandenbergh, J.G., Walser-Kuntz, D.R. and vom Saal, F.S. (2007) In vivo effects of bisphenol A in laboratory rodent studies. Reprod. Toxicol., 24, 199-224.

13. Vandenberg, L.N., Hauser, R., Marcus, M., Olea, N. and Welshons, W.V. (2007) Human exposure to bisphenol A (BPA). Reprod. Toxicol., 24, 139-177.

14. Patisaul, H.B., Fortino, A.E. and Polston, E.K. (2006) Neonatal genistein or bisphenol-A exposure alters sexual differentiation of the AVPV. Neurotoxicol. Teratol., 28, 111-118.

15. Rubin, B.S., Lenkowski, J.R., Schaeberle, C.M., Vandenberg, L.N., Ronsheim, P.M., and Soto, A.M. (2006) Evidence of altered brain sexual differentiation in mice exposed perinatally to low, environmentally relevant levels of bisphenol A. Endocrinology, 147, 3681-3691.

16. Kawai, K., Nozaki, T., Nishikata, H., Aou, S., Takii, M. and Kubo, C. (2003) Aggressive behavior and serum testosterone concentration during the maturation process of male mice: the effects of fetal exposure to bisphenol A. Environ. Health Perspect., 111, 175-178.

17. Porrini, S., Belloni, V., Della Seta, D., Farabollini, F., Giannelli, G. and Dessì-Fulgheri, F. (2005) Early exposure to a low dose of bisphenol A affects socio-sexual behavior of juvenile female rats. Brain Res. Bull., 65, 261-266.

18. Miyagawa, K., Narita, M., Narita, M., Akama, H. and Suzuki, T. (2007) Memory impairment associated with a dysfunction of the hippocampal cholinergic system induced by prenatal and neonatal exposures to bisphenol-A. Neurosci. Lett., 418, 236-241.

19. Tian, Y.H, Baek, J.H., Lee, S.Y. and Jang, C.G. (2010) Prenatal and postnatal exposure to bisphenol a induces anxiolytic behaviors and cognitive deficits in mice. Synapse, 64, 432439.

20. Xu, X.H., Zhang, J., Wang, Y.M., Ye, Y.P. and Luo, Q.Q. (2010) Perinatal exposure to bisphenol-A impairs learningmemory by concomitant down-regulation of N-methyl-Daspartate receptors of hippocampus in male offspring mice. Horm. Behav., 58, 326-333.

21. Cox, K.H., Gatewood, J.D., Howeth, C. and Rissman, E.F. (2010) Gestational exposure to bisphenol A and cross-fostering affect behaviors in juvenile mice. Horm. Behav., 58, 754761.

22. Wolstenholme, J.T., Taylor, J.A., Shetty, S.R., Edwards, M., Connelly, J.J. and Rissman, E.F. (2011) Gestational exposure to low dose bisphenol A alters social behavior in juvenile mice. PLOS ONE, 6, e25448.

23. Nitschke, K.D., Lomax, L.G., Schuetz, D.J., Hopkins, P.J. and Weiss, S.K. (1988) Bisphenol A: 13-week aerosol toxicity study with Fischer 344 rats, Dow Chemical Company.

24. Lee, Y.H., Kim, D., Lee, M.J., Kim, M.J., Jang, H.S., Park, S.H., Lee, J.M., Lee, H.Y., Park, C.B., Han, B.S., Son, W.C., Kang, J.S. and Kang, J.K. (2016) Subchronic toxicity of Acorus gramineus rhizoma in rats. J. Ethnopharmacol., 183, 46-53.

25. Song, J.C., Seo, M.K., Park, S.W., Lee, J.G. and Kim, Y.H. (2016) Differential effects of olanzapine and haloperidol on MK-801-induced memory Impairment in mice. Clin. Psychopharmacol. Neurosci., 14, 279-285.

26. Tyl, R.W., Myers, C.B., Marr, M.C., Thomas, B.F., Keimow- 
itz, A.R., Brine, D.R., Veselica, M.M., Fail, P.A., Chang, T.Y., Seely, J.C., Joiner, R.L., Butala, J.H., Dimond, S.S., Cagen, S.Z., Shiotsuka, R.N., Stropp, G.D. and Waechter, J.M. (2002) Three-generation reproductive toxicity study of dietary bisphenol A in CD Sprague-Dawley rats. Toxicol. Sci., 68, 121-146.

27. Tyl, R.W., Myers, C.B., Marr, M.C., Sloan, C.S., Castillo, N.P., Veselica, M.M., Seely, J.C., Dimond, S.S., Van Miller, J.P., Shiotsuka, R.N., Beyer, D., Hentges, S.G. and Waechter, J.M., Jr. (2008) Two-generation reproductive toxicity study of dietary bisphenol A in CD-1 (Swiss) mice. Toxicol. Sci., 104, 362-384.

28. Morrissey, R.E., George, J.D., Price, C.J., Tyl, R.W., Marr, M.C. and Kimmel, C.A. (1987) The developmental toxicity of bisphenol A in rats and mice. Fundam. Appl. Toxicol., 8, 571582.

29. Kim, J.C., Shin, H.C., Cha, S.W., Koh, W.S., Chung, M.K. and Han, S.S. (2001) Evaluation of developmental toxicity in rats exposed to the environmental estrogen bisphenol A during pregnancy. Life Sci., 69, 2611-2625.

30. Alonso-Magdalena, P., Vieira, E., Soriano, S., Menes, L., Burks, D., Quesada, I. and Nadal, A. (2010) Bisphenol A exposure during pregnancy disrupts glucose homeostasis in mothers and adult male offspring. Environ. Health Perspect., 118, 1243-1250.

31. Ho, S.M., Tang, W.Y., Belmonte de Frausto, J. and Prins, G.S. (2006) Developmental exposure to estradiol and bisphenol A increases susceptibility to prostate carcinogenesis and epigenetically regulates phosphodiesterase type 4 variant 4 . Cancer Res., 66, 5624-5632.

32. Soto, A.M., Vandenberg, L.N., Maffini, M.V. and Sonnenschein, C. (2008) Does breast cancer start in the womb? Basic Clin. Pharmacol. Toxicol., 102, 125-133.

33. Weber Lozada, K. and Keri, R.A. (2011) Bisphenol A increases mammary cancer risk in two distinct mouse models of breast cancer. Biol. Reprod., 85, 490-497.

34. Lewis, R.W., Billington, R., Debryune, E., Gamer, A., Lang, B. and Carpanini, F. (2002) Recognition of adverse and non- adverse effects in toxicity studies. Toxicol. Pathol., 30, 66-74.

35. Nah, W.H., Park, M.J. and Gye, M.C. (2011) Effects of early prepubertal exposure to bisphenol A on the onset of puberty, ovarian weights, and estrous cycle in female mice. Clin. Exp. Reprod. Med., 38, 75-81.

36. Matagne, V., Rasier, G., Lebrethon, M.C., Gerard, A. and Bourguignon, J.P. (2004) Estradiol stimulation of pulsatile gonadotropin-releasing hormone secretion in vitro: correlation with perinatal exposure to sex steroids and induction of sexual precocity in vivo. Endocrinology, 145, 2775-2783.

37. Tian, D., Xu, X.H., Ho, X., Chen, L., Xie, L.D. and Li, T. (2011) Effects of adulthood exposure to bisphenol-A on behaviors in mice. Acta Psychol. Sin., 43, 534-543.

38. Jones, B.A. and Watson, N.V. (2012) Perinatal BPA exposure demasculinizes males in measures of affect but has no effect on water maze learning in adulthood. Horm. Behav., 61, 605610.

39. Isgor, C. and Sengelaub, D.R. (1998) Prenatal gonadal steroids affect adult spatial behavior, CA1 and CA3 pyramidal cell morphology in rats. Horm. Behav., 34, 183-198.

40. Isgor, C. and Sengelaub, D.R. (2003) Effects of neonatal gonadal steroids on adult CA3 pyramidal neuron dendritic morphology and spatial memory in rats. J. Neurobiol., 55, 179-190.

41. Sohoni, P. and Sumpter, J.P. (1998) Several environmental oestrogens are also anti-androgens. J. Endocrinol., 158, 327339.

42. Leranth, C., Szigeti-Buck, K., Maclusky, N.J. and Hajszan, T. (2008) Bisphenol A prevents the synaptogenic response to testosterone in the brain of adult male rats. Endocrinology, 149, 988-994.

43. Xu, X., Liu, Y., Sadamatsu, M., Tsutsumi, S., Akaike, M., Ushijima, H. and Kato, N. (2007) Perinatal bisphenol A affects the behavior and SRC-1 expression of male pups but does not influence on the thyroid hormone receptors and its responsive gene. Neurosci. Res., 58, 149-155. 